\title{
TIGA GERAKAN MORAL SEBAGAI HUKUM ADAT MASYARAKAT SUMBA TENGAH
}

\author{
Umbu Rauta, Indirani Wauran, Arie Siswanto, Dyah Hapsari P. \\ Staf Pengajar Fakultas Hukum Universitas Kristen Satya Wacana \\ Korespondensi: umburauta@yahoo.com
}

\begin{abstract}
Abstrak
Artikel ini mendeskripsikan bahwa Tiga Gerakan Moral (Gerakan Kembali ke Kebun, Gerakan Hidup Hemat dan Gerakan Desa Aman) yang dicanangkan oleh Pemerintah Daerah bersama komponen-komponen masyarakat adat di Kabupaten Sumba Tengah merupakan hukum adat. Tiga Gerakan Moral sebagai hukum adat didasarkan pada pemenuhan unsur-unsur hukum adat yaitu adanya kaidah, masyarakat, sanksi, dan penegak sanksi. Selain itu, artikel ini juga memberikan argumentasi bahwa Tiga Gerakan Moral sejatinya bertujuan mencapai atau mewujudkan kesejahteraan bagi masyarakat Sumba Tengah. Hal ini disebabkan karena melalui Tiga Gerakan Moral, Pemerintah bersama masyarakat bermaksud menyelesaikan persoalan mendasar yang ada yaitu kecenderungan mengabaikan penggarapan lahan kebun, kecenderungan menafsirkan nilai budaya secara kurang tepat sehingga bermuara pada gaya hidup hedonistik, serta gangguan keamanan yang masih cukup tinggi.
\end{abstract}

\section{Kata kunci: Tiga Gerakan Moral; Hukum Adat, Sumba Tengah.}

\begin{abstract}
This article argues that the Three Moral Movements (Back to Field Movement, the Safe Village Movement and the Frugal Lifestyle Movement) launched by the local government and prominent figures of traditional community in Central Sumba Regency meets the qualification of customary law. The categorization of the Three Moral Movements as customary law is based on the fact that the movements consist of customary norms, have been implemented among the traditional community members, and equipped with sanctions as well as the law enforcement elements. Additionally, this article also argues that the Three Moral Movements aims to achieve prosperity for the people of Central Sumba. This is because through the Three Moral Movements, the Government along with the community intends to resolve the existing fundamental problems, which are the tendency of ignoring the cultivation of idle fields, the tendency to mistakenly interpret cultural values that leads to a hedonistic lifestyle, as well as significant security issues.
\end{abstract}

Keywords: Three Moral Movements; Customary Law; Central Sumba.

Artikel ini bersumber dari sebagian hasil penelitian yang dilakukan di Kabupaten Sumba Tengah Provinsi Nusa Tenggara Timur Tengah tahun 2012. 


\section{PENDAHULUAN}

Kabupaten Sumba Tengah di wilayah Provinsi Nusa Tenggara Timur merupakan daerah otonom baru yang ditetapkan berdasarkan UndangUndang Nomor 3 Tahun 2007 tentang Pembentukan Kabupaten Sumba Tengah, yang sebelumnya daerah ini merupakan bagian dari Kabupaten Sumba Barat. Kabupaten Sumba Tengah memiliki 5 (lima) kecamatan, yaitu: Kecamatan Katiku Tana, Kecamatan Katiku Tana Selatan, Kecamatan Umbu Ratu Nggay, Kecamatan Mamboro, dan Kecamatan Umbu Ratu Nggay Barat. Sebagai daerah otonom baru, ada sejumlah masalah dan tantangan yang harus diselesaikan sebagai bagian dari usaha mensejahterakan masyarakat. Salah satu upaya dalam rangka menyelesaikan permasalahan tersebut yaitu dengan mencanangkan Tiga Gerakan Moral yang terdiri atas: Gerakan Kembali ke Kebun, Gerakan Hidup Hemat, dan Gerakan Desa Aman.

Pertama, Gerakan Kembali ke Kebun, dimaksudkan untuk memanfaatkan potensi sumber daya alam yang tersedia dalam rangka pemenuhan kebutuhan masyarakat dan untuk meningkatkan ketahanan pangan masyarakat. Gerakan ini bukan gerakan artifisial yang muncul dalam waktu singkat, melainkan sebuah produk kontemplasi atas nilai-nilai kultural yang mengacu pada sikap hidup orang Sumba Tengah yang secara tradisional memandang kebun/lahan sebagai sumber penghidupan. Hal ini tercermin dari ungkapan "haka tana mangami rutu" (mencangkul tanah, mencabut rumput) dan "taungu pini manu, taungu auhu wawi" (memberi makan ayam, memberi makan ternak).

Gerakan Kembali ke Kebun dicanangkan dengan mempertimbangkan dua kondisi yang terjadi yaitu rendahnya pemanfaatan lahan/kebun secara optimal oleh masyarakat dan keadaan rawan pangan dan kemiskinan yang seakan-akan menjadi 'trade mark' bagi wilayah Provinsi Nusa Tenggara Timur, termasuk Kabupaten Sumba Tengah. Bertolak dari dua kondisi tersebut, gerakan ini merupakan upaya mengoptimalkan pengelolaan dan pemanfaatan lahan/kebun untuk mengatasi persoalan rawan pangan dan kemiskinan. Gerakan ini juga dimaksudkan sebagai upaya untuk meningkatkan penganeka-ragaman konsumsi pangan lokal yang tidak semata-mata tergantung pada konsumsi beras.

Kedua, Gerakan Hidup Hemat dimaknai sebagai gerakan untuk mendorong masyarakat memanfaatkan apa yang mereka miliki secara bijak berdasarkan prioritas kebutuhan. Gerakan ini juga memiliki akar kultural di dalam masyarakat sehingga bukan sekedar gerakan artifisial dari luar masyarakat. Gerakan Hidup Hemat dimaksudkan sebagai upaya mengurangi gaya hidup boros masyarakat Sumba Tengah, terutama yang diekspresikan melalui acara-acara adat yang memerlukan biaya besar. Gerakan ini tidak dimaksudkan untuk 
me-reduksi makna simbol-simbol kultural dalam upacara-upacara adat (seperti perkawinan, kematian, dan pesta adat lainnya), melainkan justru untuk mengembalikan simbol dan makna adat kepada hakikat semula. Dengan demikian, gerakan ini justru "memurnikan" nilai-nilai hakiki yang terkandung di dalam upacara-upacara adat, yang belakangan ini sempat bertumpang-tindih dengan kepentingan lain, yaitu berkaitan dengan "harga diri" atau "prestige".

Gerakan Hidup Hemat dinilai baik karena pada akhirnya penerima manfaat adalah masyarakat. Penentuan prioritas kebutuhan serta pembatasan pengeluaran dalam penyelenggaraan upacara adat akan membuat masyarakat mengalokasikan sumber daya yang dimiliki untuk kebutuhan lain yang lebih penting seperti pendidikan dan kesehatan dan tidak dihabiskan untuk kegiatan konsumtif.

Ketiga, Gerakan Desa Aman, dipahami sebagai gerakan untuk mewujudkan ketenteraman dan ketertiban, yang tergambar dari kondisi masyarakat yang tidak terancam oleh gangguan keamanan saat mereka beraktivitas. Fenomena pencurian atau perampokan ternak yang jamak terjadi, keprihatinan terhadap peredaran dan konsumsi minuman beralkohol yang tidak terkendali, fenomena perjudian, perselisihan atau konflik antar kelompok masyarakat, merupakan pendorong munculnya Gerakan Desa Aman tersebut.

Gerakan Desa Aman juga memiliki tujuan lebih jauh yaitu membebaskan masyarakat dari rasa takut, sehingga masyarakat bisa menjalankan aktivitas dengan tenteram, termasuk aktivitas ekonomi (beternak, bertani), sehingga pada akhirnya aktivitas ekonomi dapat berjalan dengan baik dan memberikan kontribusi bagi kesejahteraan masyarakat sendiri. Tujuan ini dipandang sebagai tujuan yang positif dan sejalan dengan kehendak masyarakat Sumba Tengah sebagai masyarakat yang rukun dan damai (moruku pa angngungu).

Berdasarkan uraian sebelumnya, dirumuskan permasalahan penelitian sebagai berikut: (i) Apakah yang melatarbelakangi lahirnya atau dicanangkannya Tiga Gerakan Moral di Kabupaten Sumba Tengah? (ii) Apakah Tiga Gerakan Moral merupakan hukum adat masyarakat di Kabupaten Sumba Tengah ? (iii) Apakah Tiga Gerakan Moral tersebut memiliki arti penting untuk perwujudan kesejahteraan masyarakat?

Penelitian ini adalah penelitian hukum empiris ${ }^{2}$ atau penelitian hukum nondoktrinal. ${ }^{3}$ Penelitian hukum nondoktrinal menempatkan hasil amatan atas realitas-realitas sosial untuk ditempatkan sebagai proposisi umum

Soerjono Soekanto dan Sri Mamuji, Penelitian Hukum Normatif Sebuah Tinjauan Singkat (Rajawali Pers 1990) 15.

Sulistyowati Irianto \& Shidarta (Editor), Metode Penelitian Hukum: Konstelasi dan Refleksi (Yayasan Pustaka Obot Indonesia 2011) 121. 
alias premis mayor. Oleh karena merupakan penelitian empiris maka sumber data berfokus pada data primer, yang diperoleh dengan melakukan wawancara terhadap pihak-pihak yang terlibat secara langsung (key informant) maupun studi kepustakaan terhadap dokumen-dokumen penting. Spesifikasi penelitian ini yaitu penelitian deskriptif, yang oleh Sugeng Istanto ${ }^{4}$ dimaknai sebagai suatu penelitian yang bertujuan untuk menggambarkan keberadaan suatu kebenaran hukum seperti apa adanya.

\section{PEMBAHASAN}

\section{Latar belakang lahirnya Tiga Gerakan Moral}

Tiga Gerakan Moral lahir merupakan respon atas perkembangan masyarakat Sumba Tengah yang diperhadapkan pada 3 (tiga) masalah dasar. Pertama, pergeseran pola bertani masyarakat yang sebelumnya berorientasi kebun dan sawah yang dikerjakan secara paralel dan berimbang menjadi hanya berfokus pada sawah atau proporsi pengelolaan kebun semakin kecil bahkan ditinggalkan sebagai sumber ketersediaan pangan dan komoditi perdagangan. Kedua, kecenderungan hedonisme yang bertamengkan adat istiadat sehingga tidak lagi melestarikan substansi hubungan kekerabatan antar manusia yang saling melengkapi tetapi lebih cenderung menjadi even prestisius yang justru memarginalkan nilai dan prinsip relasi sosial budaya yang sesungguhnya. Ketiga, tidak terkendalinya masalah ketentraman ketertiban masyarakat, utamanya pencurian dan perampokan ternak serta peredaran minuman beralkohol.

Terkait dengan masalah pertama, pergeseran pola bertani dari kebun ke sawah dan atau pola bertani yang hanya mengandalkan sawah tadah hujan telah mengancam ketahanan pangan masyarakat. Hal ini terjadi karena hasil sawah hanya berupa padi sedangkan palawija dan hortikultura yang seharusnya dihasilkan melalui kebun tidak mendapat porsi pengembangan dalam usaha pertanian. Hal ini lebih diperparah dengan kondisi sebagian besar sawah-sawah yang ada merupakan sawah tadah hujan yang hanya memberi hasil panen sekali dalam setahun. Pada pihak lain kebun (modu, oma, dan kaliwu) memiliki daya tahan yang cukup terhadap labilitas curah hujan dan merupakan simbol ketahanan pangan orang Sumba. Hal ini disebabkan karena melalui pengusahaan kebun, terdapat sumber produksi komoditi perdagangan seperti kopi, kemiri, asam, dan lain sebagainya. Melalui kebun pula, masyarakat dapat memelihara ternak, oleh karena pakan ternak tersedia dalam jumlah yang cukup.

Terkait dengan masalah kedua, pola hedonisme bertamengkan adat istiadat menjadikan masyarakat tidak

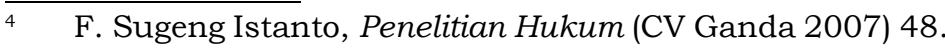


dapat meningkatkan derajat kehidupannya. Kegemaran untuk membantai (baca: mempersembahkan) ternak dalam jumlah banyak pada upacara adat hingga ritus-ritus kematian serta besaran jumlah belis ${ }^{5}$ yang sudah menyimpang dari filosofi belis sesungguhnya juga bertentangan dengan prinsip dan nilai budaya dan mengkerdilkan potensi masyarakat Sumba Tengah untuk dapat meningkatkan kualitas hidupnya.

Terkait dengan masalah ketiga, tidak terkendalinya masalah ketentraman dan ketertiban masyarakat terutama yang berkaitan dengan meningkatnya intensitas pencurian dan perampokan ternak telah menghasilkan masalah ganda, yaitu pencurian ternak berimplikasi pada pemiskinan secara cepat dan pada akhirnya menyurutkan minat masyarakat untuk beternak.

Selanjutnya, dari hasil wawancara dengan Bupati Sumba Tengah Drs. Umbu S. Pateduk, terungkap latar belakang dari dicanangkannya Tiga Gerakan Moral tersebut ${ }^{6}$ yaitu:

a. Untuk Gerakan Kembali ke Kebun. Di satu sisi Kabupaten Sumba Tengah memiliki potensi sumber daya berupa tanah yang jika diolah dengan baik dapat menjadi sumber kesejahteraan masyarakat. Di sisi lain, tidak dapat dipungkiri bahwa selama beberapa waktu, Provinsi Nusa Tenggara Timur, termasuk
Kabupaten Sumba Tengah memiliki label sebagai wilayah rawan kelaparan dan rawan kemiskinan. Gerakan ini dimaksudkan untuk memanfaatkan potensi yang terkandung dalam sumber daya tanah/ lahan agar dapat dipergunakan untuk mengatasi persoalan rawan pangan, memenuhi kebutuhan asupan protein dan gizi masyarakat, serta menjadi sumber penghasilan bagi masyarakat melalui perdagangan hasil bumi. Pentingnya pengelolaan lahan/tanah secara baik sebenarnya bukan merupakan hal baru bagi masyarakat yang sejak nenek moyang mereka meyakini bahwa tanah adalah sumber kesejahteraan. Bahwa manusia lahir dari tanah, hidup dari tanah dan mati kembali menjadi tanah. Dengan demikian, gerakan ini adalah ajakan untuk menghayati kembali keyakinan bahwa tanah adalah sumber kesejahteraan. Pemanfaatan potensi tanah dalam kerangka menghilangkan "trade mark" Kabupaten Sumba Tengah sebagai wilayah yang identik dengan rawan pangan dan rawan gizi adalah sebuah upaya yang realistis, karena dengan etos kerja yang tinggi di dalam mengolah lahan, tanah di Sumba yang sesungguhnya subur bisa memberi hasil yang baik. Apabila lahan-lahan "tidur" itu dikelola

\footnotetext{
Belis adalah sejumlah barang (termasuk hewan/ternak) yang menjadi "alat" dalam membentuk hubungan perkawinan.

$6 \quad$ Wawancara dilakukan di Ruang Kerja Bupati, pada Sabtu, 19 November 2011 Pukul 09.00 -
} 10.15. wita) 
dengan baik, perdagangan komoditas yang merupakan hasil kebun itu bisa menghasilkan pendapatan untuk memenuhi kebutuhan sehari-hari keluarga dan bahkan hasilnya dapat ditabung untuk kebutuhan jangka panjang seperti kebutuhan pendidikan dan kesehatan.

b. Untuk Gerakan Hidup Hemat. Salah satu ciri komunalitas masyarakat adalah selalu membutuhkan keterlibatan orang lain dalam tahapan-tahapan penting kehidupannya, termasuk juga dalam perkawinan. Bagi masyarakat Sumba Tengah, perkawinan dipandang sebagai awal pembentukan hubungan kemanusiaan, sehingga acara ini harus melibatkan banyak orang. Sebagai sarana untuk menandai keterbentukan hubungan kemanusiaan melalui perkawinan ini, masyarakat menggunakan lembaga 'belis' berupa penyerahan sejumlah hewan/ternak dan barang lainnya. Pada awalnya, karena hanya merupakan sarana simbolik bagi hubungan kemanusiaan yang terbentuk melalui perkawinan, jumlah 'belis' pun tidak banyak, berkisar antara 11 hingga 17 ekor ternak. Namun, dalam perjalanan waktu, terjadi deviasi dalam hal jumlah 'belis' yang kemudian menjadi salah satu 'penanda' bagi status sosial. Pergeseran fungsi 'belis' dari fungsi kultural menjadi fungsi sosioekonomi ini kemudian membawa konsekuensi yang tidak ringan bagi masyarakat yang masih melihat bahwa 'belis' menentukan status sosial mereka, yang kemudian merasa "berkewajiban" untuk menuntut dan memberikan 'belis' dalam jumlah yang besar. Peristiwa lain yang juga melibatkan "kewajiban" untuk menyediakan ternak dalam jumlah besar adalah peristiwa kematian. Masyarakat Sumba Tengah pada umumnya memiliki pandangan bahwa peristiwa kematian harus dibarengi dengan acara jamuan makan. Persoalannya, pada praktiknya, dalam satu hari bisa ada lebih dari 1 ternak yang dipotong untuk memenuhi kebutuhan ini. Pemotongan hewan untuk jamuan makan akan terus berlangsung hingga saat pemakaman/pekuburan. Pada saat penguburan, pihak keluarga juga masih harus menyembelih ternak dalam jumlah yang cukup banyak. Sebenarnya pemotongan ternak dalam peristiwa-peristiwa perkawinan dan kematian sejatinya merefleksikan pandangan tentang "kesatuan manusia dengan ternak" yang menjadi prinsip masyarakat Sumba. Namun demikian, ketika prinsip adat ini diaplikasikan secara berlebihan, ia justru akan menjadi adat yang memiskinkan masyarakat secara sistematik. Gerakan ini merupakan upaya untuk memurnikan nilai-nilai kultural masyarakat agar nilai-nilai tersebut benar-benar mencerminkan jati diri manusia Sumba Tengah secara hakiki dan tidak terkontaminasi 
oleh pandangan-pandangan lain yang "mendompleng" nilai-nilai ini, yang justru dapat memiskinkan masyarakat. Melalui penyederhanaan dan penghematan, - tanpa harus menghapuskan makna kultural ternak - , diharapkan masyarakat akan memiliki daya dukung ekonomi yang lebih baik.

c. Untuk Gerakan Desa Aman. Gerakan ini dilandasi oleh pandangan bahwa dinamika ekonomi, termasuk dinamika ekonomi rakyat yang didorong oleh Gerakan Kembali ke Kebun dan Gerakan Hidup Hemat, membutuhkan dukungan situasi tenteram dan aman dalam pergaulan hidup bermasyarakat. Ketenteraman dan keamanan menjadi prasyarat bagi dinamika ekonomi. Tugas pemerintah adalah memberikan ketenteraman dan keamanan bagi masyarakat. Problem yang muncul yaitu pencurian ternak, konsumsi minuman beralkohol, perjudian, dll. Pencurian tidak saja mengganggu ketentraman dan ketertiban masyarakat tetapi juga menghilangkan sumber-sumber ekonomi rakyat, seperti hewan ternak dan hasil pertanian. Perilaku mengkonsumsi minuman beralkohol pada gilirannya berpotensi terjadinya tindakan melawan hukum, baik berupa perkelahian dan pencurian/perampokan.

Beberapa masalah dan latar-belakang tersebut akhirnya dipercakapkan dalam forum Seminar dan Musya- warah Adat yang digagas dan dilaksanakan oleh Pemerintah Kabupaten Sumba Tengah pada awal tahun 2010. Forum tersebut dihadiri oleh tokoh adat, tokoh masyarakat, tokoh agama, tokoh pemuda, pihak lain yang terkait se wilayah Kabupaten Sumba Tengah. Hasil dari forum dimaksud berupa komitmen masyarakat untuk melakukan penanganan terhadap beberapa permasalahan mendasar tersebut dalam sebuah rumusan gerakan yaitu Tiga Gerakan Moral. Tiga Gerakan Moral ini telah menjadi tekad masyarakat bersama pemerintah, sebagaimana tergambar melalui pernyataan sikap dan tekad serta sumpah adat untuk mendukung dan melaksanakan Tiga Gerakan Moral tersebut, mulai dari tingkat desa, kecamatan, dan puncaknya pada tingkat kabupaten pada tanggal 28 Oktober 2010.

Adapun lingkup dan substansi Tiga Gerakan Moral tersebut tampak pada Tabel 1.

\section{Tiga Gerakan Moral sebagai Hukum Adat}

Adat pada dasarnya adalah kebiasaan yang berulang, yang telah berwujud aturan tingkah laku yang berlaku di masyarakat dan dipertahankan masyarakat. ${ }^{7}$ Lebih lanjut dikatakan bahwa adat merupakan ketentuan yang timbul serta tumbuh dari dalam masyarakat itu sendiri, yang kemudian ditaati sebagai hukum. Dikatakan hukum karena yang dimak-

Hilman Hadikusumah, Pokok-Pokok Pengertian Hukum Adat (Alumni 1980) 16-19. 
sud dalam hal ini adalah adat yang memiliki sanksi, yaitu adat yang mengandung perintah dan larangan dan apabila dilanggar maka si pelanggar akan mendapat ancaman dari masyarakat adat. $^{8}$

Secara konstitusional, pengakuan secara tidak langsung oleh negara terhadap eksistensi adat tampak pada pengaturan Pasal 18B ayat (2) UUD Negara Republik Indonesia Tahun 1945. Dalam pasal a quo, negara mengakui dan menghormati kesatuankesatuan masyarakat hukum adat beserta hak-hak tradisionalnya sepanjang masih hidup dan sesuai dengan perkembangan masyarakat dan prinsip Negara Kesatuan Republik Indonesia. Berdasarkan materi konstitusi tersebut jelas bahwa ketika ada pengakuan dan penghormatan negara terhadap kesatuan masyarakat adat, maka produk masyarakat berupa adat dan hukum adat juga memperoleh pengakuan dan penghormatan sepanjang masih eksis dan tidak merongrong eksistensi negara Indonesia sebagai negara kesatuan.

Tabel 1 Tiga Gerakan Moral di Kabupaten Sumba Tengah ${ }^{9}$

\begin{tabular}{|c|c|c|c|}
\hline & $\begin{array}{c}\text { Gerakan Kembali } \\
\text { ke Kebun }\end{array}$ & Gerakan Hidup Hemat & Gerakan Desa Aman \\
\hline $\begin{array}{l}1 . \\
2 . \\
3 . \\
4 . \\
5 .\end{array}$ & $\begin{array}{l}\text { Kepemilikan kebun } \\
\text { (luas lahan) } \\
\text { Jam Kerja } \\
\text { Jenis Tanaman } \\
\text { Kewajiban Gotong } \\
\text { Royong } \\
\text { Sanksi adat berupa } \\
\text { Ruatu: yaitu } \\
\text { pelayanan makan dan } \\
\text { minum bagi seluruh } \\
\text { warga desa atau } \\
\text { kecamatan dengan } \\
\text { menyembelih ternak } \\
\text { berupa kerbau dan } \\
\text { babi. Kemudian sanksi } \\
\text { lain berupa denda } \\
\text { dalam wujud uang. } \\
\text { Selain sanksi adat, } \\
\text { juga dimungkinkan } \\
\text { berlakunya sanksi } \\
\text { nasional, khusus } \\
\text { untuk pelanggaran } \\
\text { terhadap gerakan desa } \\
\text { aman. }\end{array}$ & $\begin{array}{l}\text { 1. Penyederhanaan ritual } \\
\text { belis (terutama jumlah } \\
\text { hewan/barang) } \\
\text { 2. Batas waktu } \\
\text { penyemayaman jenazah } \\
\text { 3. Pembatasan pemotongan } \\
\text { hewan saat ritual } \\
\text { kematian dan ritual } \\
\text { umum lainnya. } \\
\text { 4. Sanksi berupa Ruatu } \\
\text { yaitu pelayanan makan } \\
\text { dan minum bagi seluruh } \\
\text { warga desa atau } \\
\text { kecamatan dengan } \\
\text { menyembelih ternak } \\
\text { berupa kerbau dan babi. } \\
\text { Sanksi lain berupa } \\
\text { denda dalam wujud } \\
\text { uang. Selain sanksi adat, } \\
\text { dimungkinkan } \\
\text { berlakunya sanksi } \\
\text { nasional, untuk } \\
\text { pelanggaran terhadap } \\
\text { gerakan desa aman. }\end{array}$ & $\begin{array}{l}\text { 1. Kewajiban siskamling } \\
\text { bagi tiap desa. } \\
\text { 2. Jam malam } \\
\text { 3. Larangan judi dan } \\
\text { mengkonsumsi } \\
\text { minuman beralkohol } \\
\text { 4. Larangan kawin } \\
\text { paksa } \\
\text { 5. Sanksi berupa Ruatu } \\
\text { yaitu pelayanan } \\
\text { makan dan minum } \\
\text { bagi seluruh warga } \\
\text { desa atau kecamatan } \\
\text { dengan menyembelih } \\
\text { ternak berupa kerbau } \\
\text { dan babi. Kemudian } \\
\text { sanksi lain berupa } \\
\text { denda dalam wujud } \\
\text { uang. Selain sanksi } \\
\text { adat, juga } \\
\text { dimungkinkan } \\
\text { berlakunya sanksi } \\
\text { nasional, khusus } \\
\text { untuk pelanggaran } \\
\text { terhadap gerakan } \\
\text { desa aman. }\end{array}$ \\
\hline
\end{tabular}

8 Hilman Hadikusumah, Ibid., 26.

$9 \quad$ Umbu Rauta et.al., Tiga Gerakan Moral (Perspektif Historis, Filosofis, Yuridis dan Sosiologis), Hasil Penelitian Kerjasama antara Fakultas Hukum UKSW dengan Pemerintah Kabupaten Sumba Tengah, 2012. 74-95 (Diolah). 
Beranjak dari pendapat di atas, dapat dikatakan bahwa Tiga Gerakan Moral merupakan cerminan adat istiadat masyarakat Sumba Tengah yang bersumber dari nilai-nilai yang telah diyakini kebenarannya secara turuntemurun, yang dapat diuraikan berikut ini. Gerakan Kembali ke Kebun pada dasarnya bersumber dari keyakinan masyarakat bahwa tanah adalah sumber kesejahteraan, sehing-ga gerakan ini sejatinya merupakan ajakan untuk menghayati keyakinan tersebut. Gerakan Hidup Hemat merupakan cerminan dari salah satu pandangan masyarakat yang erat kaitannya dengan kedudukan hewan/ ternak bagi masyarakat Sumba Tengah dalam ikatan kesatuan antara manusia dengan hewan/ternak. Pemberian ternak atau pemotongan ternak dalam peristiwa-peristiwa tertentu (ritual perkawinan, kematian, dan lain-lain) menjadi hal yang penting bagi masyarakat. Gerakan ini merupakan ajakan pemurnian nilai-nilai budaya agar tetap memiliki makna yang hakiki dan tidak berujung pada pemberian dan pemotongan ternak secara eksesif. Gerakan Desa Aman merupakan dukungan terhadap upaya peningkatan ketenteraman dan keamanan masyarakat yang menjadi prasyarat bagi dinamika ekonomi. Gerakan ini berdasar pada prinsip masyarakat adat yang menginginkan keseimbangan dalam kehidupan.
Sementara itu, hukum adat merupakan kesepakatan adat yang di dalamnya terdapat sanksi. Sanksi ini diperlukan untuk mengembalikan keseimbangan dalam masyarakat yang dianggap terganggu ketika sebuah norma adat dilanggar. Baik hukum adat maupun sanksi yang menyertainya bersifat dinamis, sehingga norma dan sanksi hukum adat dapat berubah sesuai dengan perubahan nilai-nilai yang terjadi dalam masyarakat. Van Vollenhoven mendefinisikan Hukum Adat sebagai keseluruhan aturan tingkah laku positif di mana di satu pihak mempunyai sanksi sedangkan di pihak lain tidak dikodifikasi. ${ }^{10}$

Tiga Gerakan Moral merupakan cerminan dari adat istiadat masyarakat Sumba Tengah, yang kemudian melahirkan kesepakatan bersama yang juga dilengkapi dengan sanksi bagi mereka yang melakukan pelanggaran. Kesepakatan ini berawal dari lingkup desa, kecamatan dan kabupaten dengan dihadiri oleh tokoh adat, tokoh masyarakat dan pemerintah setempat. Kehadiran perwakilan tokoh adat dan tokoh masyarakat menunjukkan bahwa ada otoritas masyarakat adat yang terlibat dalam proses membuat keputusan. Apa yang telah disepakati dan diputuskan oleh tokoh adat pada dasarnya merupakan keputusan adat yang harus diikuti oleh masyarakat adat. Hal ini sejalan dengan

10 Agus Dwi Santoso, Peran dan Fungsi Kedudukan Hukum Adat Dalam Sistem Hukum Nasional Dalam Rangka Penguatan dan Pelestarian Nilai-Nilai Adat Istiadat Di Daerah (2011), <http:// geosmanda.blogspot.com/2011/11/peran-dan-fungsi-kedudukan-hukum-adat.html. Diakses tanggal 16 Februari $2017>$. 
pendapat Ter Haar yang menyatakan bahwa pada saat penetapan peraturan adat oleh petugas hukum adat, maka pada saat itu peraturan tersebut berlaku sebagai hukum adat. ${ }^{11} \mathrm{Hal}$ lain yang juga memperkuat karak-teristik hukum adat yaitu pengesahan kesepakatan-kesepakatan yang telah dibuat tersebut dalam sebuah upacara adat. Upacara adat memiliki kedudukan yang tinggi dan dihormati oleh masyarakat Sumba Tengah.

Sebagai norma yang lahir dari masyarakat, dari perspektif Von Savigny, Tiga Gerakan Moral merupakan hukum adat yang tumbuh dan berkembang dalam rahim jiwa masyarakat (volksgeist, spirit of the people) Sumba Tengah. Hukum yang tumbuh dari antara masyarakat sendiri secara teoritik akan lebih mampu menjawab kebutuhan masyarakat akibat perubahan-perubahan sosial, serta lebih mampu memenuhi rasa keadilan substansial masyarakat tersebut. Dengan kata lain, hukum semacam itu akan memiliki karakter sebagai hukum responsif yang memiliki daya laku kuat di dalam masyarakat.

Oleh karena lahir dari masyarakat dan diperuntukkan bagi kehidupan masyarakat Sumba Tengah, pelaksanaan Tiga Gerakan Moral yang merupakan hukum adat memiliki legitimasi sosial dan legitimasi hukum. Walaupun Tiga Gerakan Moral, sebagai hukum adat, tidak mempunyai struktur-struktur yang menciptakan kewibawaan formal seperti halnya hukum negara (state law), ia tetap memiliki kekuatan dan kewibawaan yang berbasis pada moral dan kultur. Dengan demikian, sebagai sebuah hukum adat, kesepakatankesepakatan yang dibuat memiliki legitimasi filosofis, sosiologis, dan yuridis.

Legitimasi filosofis dapat diuraikan berikut. Pertama, Gerakan Kembali ke Kebun didasarkan pada nilai filosofis yang dipegang oleh masyarakat bahwa tanah adalah sumber kesejahteraan. Gerakan ini adalah ajakan untuk menghayati kembali keyakinan bahwa tanah adalah sumber kesejahteraan bagi kehidupan masyarakat, yang untuk beberapa waktu sempat terkikis. Kedua, Gerakan Hidup Hemat didasarkan pada nilai filosofis bahwa manusia selalu membutuhkan keterlibatan orang lain dalam tahapantahapan penting kehidupannya dan pandangan bahwa manusia dan ternak adalah satu kesatuan. Ternak memiliki kedudukan yang penting bagi manusia, tampak ketika digunakan dalam ritual adat seperti kematian dan perkawinan. Gerakan ini merupakan sebuah ikhtiar untuk memurnikan nilai-nilai filosofis ini, sehingga dalam implementasinya pemberian dan pemotongan ternak tidak perlu dilakukan secara berlebihan. Ketiga, Gerakan Desa Aman didasarkan pada nilai filosofi kedekatan masyarakat Sumba terhadap ternak serta kede-

11 Soepomo, Bab-Bab tentang Hukum Adat (Pradnya Paramita 2003) 39. 
katannya dengan tanah/kebun. Pencurian dan atau perampokan terhadap ternak dan hasil bumi menggoyahkan hubungan masyarakat dengan ternak dan tanah yang dimilikinya.

Sosial-budaya masyarakat lokal. Gerakan ini merupakan salah satu kearifan lokal (local wisdom) yang memuat nilai-nilai yang akan mampu mewujudkan kedaulatan pangan (food sovereignty) serta meningkatkan pendapatan masyarakat, sehingga pada akhirnya dapat memutus rantai kemiskinan. Hal ini dapat diketahui dari beberapa kesepakatan di antaranya pengaturan kewajiban kepemilikan lahan minimal dan kewajiban setiap kepala keluarga untuk menanam tanaman pangan dan tanaman perdagangan.

Gerakan Kembali ke Kebun juga merupakan langkah mengembalikan sistem sosial kemasyarakatan para petani/masyarakat yang bukan sekedar sebagai makhluk ekonomi (homo economicus), melainkan juga sebagai makhluk sosial (homo socius) dan makhluk beragama (homo religius), yang dikaitkan dengan unsur-unsur nilai sosial-budaya lokal, yang memuat aturan dan pola hubungan sosial, politik, ekonomi, dan budaya. Hal ini tampak dalam pengaturan yang menentukan kewajiban gotong royong atau kelompok kerja tanpa adanya pembayaran upah untuk pengelolaan kebun dan sawah.
Ketiga, Gerakan Desa Aman, merupakan upaya masyarakat guna mengatasi terkikisnya rasa aman akibat maraknya pencurian dan perampokan yang menyebabkan hilangnya harta benda, khususnya ternak dan hasil pertanian. Pencurian harta benda dan ternak menghasilkan masalah ganda yaitu: pemiskinan secara cepat pada dan menyurutkan minat masyarakat untuk beternak. Oleh karenanya, melalui Gerakan Desa Aman antara lain menentukan kewajiban melaksanakan siskamling, larangan melakukan perjudian, larangan menjual serta mengkonsumsi minuman beralkohol.

Dengan demikian tiga gerakan tersebut merupakan norma yang lahir dari masyarakat yang menurut Von Savigny merupakan hukum adat yang tumbuh dan berkembang dalam rahim volksgeist. Volksgeist diartikan sebagai kesadaran umum manusia atau jiwa manusia (general consciousness of the people atau spirit of the people). ${ }^{12}$ Karena lahir dari masyarakat dan diperuntukkan dalam kehidupan komunitas masyarakat, maka Tiga Gerakan Moral yang nota bene merupakan hukum adat tersebut memiliki legitimasi sosial dan hukum bagi pelaksanaanya. Sesuai dengan pendapat Soepomo ${ }^{13}$, karena Hukum Adat berasal dari masyarakat, maka hukum adat merupakan hukum yang hidup, sebab ia menjelmakan perasaan hukum yang nyata dari rakyat.

\footnotetext{
12 Bernard L. Tanya, et.al., Teori Hukum Strategi Tertib Manusia Lintas Ruang dan Generasi (Genta Publishing 2010) 103.

13 Soepomo, Op.Cit., 3.
} 
Selanjutnya, keberlakuan atau kekuatan mengikat hukum adat juga ditentukan oleh keberadaan sanksi adat. Sanksi adat adalah komponen yang membuat adat berlaku sebagai hukum dan dikenal sebagai hukum adat. Sanksi dipahami sebagai sarana untuk menyeimbangkan kehidupan masyarakat. Dalam sistem hukum adat, segala perbuatan yang bertentangan dengan peraturan hukum adat merupakan perbuatan illegal dan hukum adat mengenal pula ikhtiarikhtiar untuk memperbaiki kembali hukum (rechtherstel) jika hukum diperkosa. ${ }^{14}$

Apabila terjadi pelanggaran hukum adat, kepala adat mengambil tindakan nyata untuk membetulkan hukum yang dilanggar itu. Tindakan yang diambil didasarkan pada rasa keadilan menurut masyarakat. Pembetulan hukum yang dilanggar itu dilakukan dengan pemberian sanksi adat. Dengan kata lain sanksi adat merupakan reaksi atas pelanggaran (delik) hukum adat yang terjadi. Sanksi adat telah ditetapkan menurut rasa keadilan masyarakat karena sanksi tersebut juga merupakan bagian yang disepakati bersama oleh masyarakat. Dengan demikian sanksi atas pelanggaran tiga gerakan mengikat masyarakat Sumba Tengah dan menjadi tugas otoritas adat untuk mengambil tindakan atas pelanggaran hukum yang terjadi. Otoritas adat yang dimaksud yaitu Lembaga Adat yang ada baik pada tingkat desa, kecamatan, dan kabu-

\footnotetext{
14 Soepomo, Ibid., 39.
}

paten. Unsur keanggotaan Lembaga Adat berasal dari tokoh adat, tokoh masyarakat dan tokoh agama, yang ditentukan oleh masyarakat yang bersangkutan serta dikukuhkan oleh Pemerintah Daerah. Adapun tugas dari Lembaga Adat yaitu: (i) menginventarisir nilai-nilai budaya lokal yang ada di tengah-tengah masyarakat untuk kemudian diangkat ke permukaan untuk menjadi rujukan dalam pelaksanaan pembangunan; dan (ii) mendorong, memotivasi, menegur dan memberi sanksi kepada masyarakat yang melakukan pengingkaran terhadap Tiga Gerakan Moral.

Dalam hal sanksi adat belum mengatur atau telah disepakati oleh masyarakat bahwa sanksi terkait dengan tindakan tertentu tunduk pada sanksi menurut hukum formal, maka yang seperti itu pun dapat diterapkan. Hal ini dimengerti sebab hukum merupakan satu sistem besar, sehingga antara hukum adat dan hukum formal (yang dibuat oleh negara) dapat saling melengkapi. Penerapan sanksi harus memperhatikan hukum yang relevan untuk menyelesaikan pelanggaran yang terjadi. Jika diselesaikan secara adat maka sanksi yang berlaku adalah sanksi adat, jika berdasar pada hukum formal maka sanksi yang berlaku adalah sanksi berdasar peraturan hukum negara yang dilanggar.

Selain sanksi, faktor lain yang juga akan mempengaruhi kualitas kepatuhan masyarakat terhadap hukum tertentu adalah keteladanan dari figurfigur yang diharapkan memiliki komit- 
men kuat terhadap pelaksanaan normanorma hukum, seperti penegak hukum, pejabat dan tokoh-tokoh masyarakat. Secara teoritik keteladanan dari figurfigur semacam itu diidentifikasi oleh Lon L.Fuller sebagai salah satu "moralitas" dari hukum yang akan menentukan kualitas penerapan hukum. Pendapat Fuller sesungguhnya bersifat universal. Ketika penegak hukum, pejabat negara dan tokoh-tokoh masyarakat menunjukkan komitmen dan konsistensi di dalam mendukung norma-norma hukum, masyarakat pada umumnya akan melihatnya sebagai hal positif. Sebaliknya, ketika figur-figur itu tidak menampakkan komitmen terhadap penerapan hukum, atau bahkan secara sengaja melanggar norma-norma hukum, sikap sinis terhadap pelaksanaan hukum tidak mustahil akan merebak di antara masyarakat. Dalam konteks Tiga Gerakan Moral, tesis ini juga berlaku, yang menghendaki adanya komitmen dari segenap komponen masyarakat Sumba Tengah, terutama dari figur-figur yang dipandang sebagai tokoh masyarakat, termasuk unsur pejabat pemerintah maupun unsur adat, termasuk anggota lembaga adat. Kemudian, legitimasi yuridis dari Tiga Gerakan Moral tersebut dapat dijelaskan berikut ini. Seperti telah dijelaskan sebelumnya, tiga gerakan merupakan kesepakatan yang dibuat mulai tingkat desa, kecamatan, sampai ting- kat Kabupaten, yang dilakukan oleh tokoh adat, tokoh agama, dan disaksikan oleh pemerintah daerah. Saat kesepakatan adat dilakukan, pemerintah, baik pada tingkat desa, kecamatan, dan kabupaten ikut bertanda tangan dalam sebagai pernyataan tekad untuk melaksanakan tiga gerakan tersebut. Sikap pemerintah yang mendukung Tiga Gerakan Moral, tidak saja merupakan perwujudan dari tugas dan kewajibannya selaku pelayan publik sebagaimana diamanatkan dalam peraturan perundang-undangan tentang pemerintahan daerah. ${ }^{15}$

Gerakan Kembali ke Kebun memiliki basis legitimasi pada perundangundangan sektoral bidang pertanian, misalnya terkait dengan budidaya tanaman. ${ }^{16}$ Sistem budidaya tanaman adalah sistem pengembangan dan pemanfaatan sumber daya alam nabati melalui upaya manusia, yang salah satu tujuannya untuk meningkatkan taraf hidup petani. Hal ini ditegaskan pula dalam Pasal 19 Peraturan Pemerintah No 18 tahun $2010^{17}$ dimana salah tujuan penyelenggaraan budi-daya tanaman adalah mewujudkan kedaulatan dan ketahanan pangan. Muara dari Gerakan Kembali ke Kebun yaitu adanya keragaman pangan dari masyarakat (selain hasil usaha pertanian di sawah) sehingga membantu ketahanan pangan masyarakat.

\footnotetext{
15 Perundang-undangan dimaksud yaitu UU No. 23 Tahun 2014 tentang Pemerintahan Daerah. Saat Tiga Gerakan ini dicanangkan, masih berlaku UU No. 32 Tahun 2004 tentang Pemerintahan Daerah.

16 Pasal 5 ayat 1 huruf d UU No. 12 tahun 1992 tentang Sistem Budidaya Tanaman.

17 PP No. 18 Tahun 2010 tentang Usaha Budidaya Tanaman
} 
Gerakan Hidup Hemat, dengan maksud pemurnian adat istiadat agar harta kekayaan (berupa ternak) lebih diutamakan untuk memenuhi kebutuhan pokok. Hal ini memiliki basis yuridis yaitu UU No. 13 tahun 2011 tentang Penanganan Fakir Miskin. Tugas penanganan fakir miskin berada di pundak pemerintah, termasuk pemerintah daerah dan juga membutuhkan partisipasi dari masyarakat (Pasal 5 No. 13 tahun 2011). Gerakan Hidup Hemat juga sesuai dengan kebijakan nasional Pemerintah sebagaimana dituangkan dalam PP No. 15 Tahun 2010. ${ }^{18}$ Dalam Pasal 1 angka 1 PP tersebut ditegaskan bahwa penanggulangan kemiskinan merupakan kebijakan pemerintah daerah yang dilakukan bersama dengan masyarakat.

Gerakan Desa Aman memiliki basis yuridis dimana warga masyarakat memiliki hak untuk memperoleh rasa aman dan hak mempertahankan hak milik siapapun juga. Hal ini memiliki landasan yuridis baik pada tataran konstitusi maupun perundang-undangan lainnya, seperti UU KUHP.

Berdasarkan pada uraian di atas maka tampak bahwa Tiga Gerakan Moral memilki kesesuaian dengan berbagai peraturan perundang-undangan nasional, sehingga memiliki legitimasi yuridis. Tiga Gerakan Moral akan memiliki daya mengikat yang kuat apabila nilai-nilai dalam gerakan tersebut dihidupkan oleh masyarakat Sumba
Tengah. Dengan kata lain, ada pengakuan yang terwujud dalam tindakan bahwa keseimbangan kehidupan masyarakat akan terwujud dalam nilai-nilai dalam Tiga Gerakan Moral. Kemudian, atas pelanggaran terhadap Tiga Gerakan Moral tersebut dikenakan sanksi oleh otoritas adat yang bertujuan untuk memperbaiki keseimbangan yang terganggu oleh pelanggaran.

Dalam kaitannya dengan hukum nasional, hukum adat harus memenuhi sejumlah syarat untuk dapat dipakai sebagai asas-asas atau landasan pembinaan hukum nasional yaitu ${ }^{19}$ :

a. Hukum adat tidak boleh bertentangan dengan kepentingan nasional yang berdasarkan atas persatuan bangsa;

b. Hukum adat tidak boleh bertentangan dengan negara Indonesia yang berfalsafah Pancasila.

c. Hukum adat tidak boleh bertentangan dengan peraturan-peraturan tertulis;

d. Hukum adat yang bersih dari sifat feodalisme, kapitalisme, serta penghisapan atas manusia;

e. Hukum adat yang tidak bertentangan dengan unsur-unsur agama.

Terkait dengan Tiga Gerakan Moral, sebagaimana telah diuraikan pada bagian sebelumnya, juga memenuhi syarat-syarat dalam pembinaan hukum nasional, yang dapat dijelaskan berikut ini. Pertama, tidak bertentangan dengan asas persatuan bangsa karena

18 PP No. 15 Tahun 2010 tentang Percepatan Penanggulangan Kemiskinan.

19 IGN Sugangga, Hukum Peranan hukum Adat dalam Pembangunan Indonesia (Pidato pengukuhan Guru Besar Hukum Adat UNDIP Semarang, 1999) $16-17$. 
tidak mengandung makna separatis; Kedua, tidak bertentangan dengan falsafah Pancasila. Ketiga, tidak bertentangan bahkan bersesuaian dengan dasar yuridis formal. Keempat, tidak ada unsur kapitalisme, feodalisme, dan penghisapan manusia. Kelima, tidak bertentangan dengan nilai-nilai agama.

Berdasar pada hal-hal di atas, maka dapat dikatakan bahwa Tiga Gerakan Moral sebagai hukum adat memenuhi syarat berlaku dalam pembinaan hukum nasional. Dengan demikian memiliki kekuatan yang mengikat masyarakat di Sumba Tengah. Pertentangan antara hukum adat dan hukum formal tidak perlu dilakukan, karena keduanya sama-sama diakui keberlakuannya sebagai bagian dari hukum nasional Indonesia. Dalam bahasa yang lain dapat dikatakan bahwa kekuatan Tiga Gerakan Moral adalah mutlak karena merupakan hukum adat. Hukum formal (hukum tertulis yang dibuat oleh negara) tetap berlaku dan mengikat masyarakat adat untuk hal-hal yang tidak diatur oleh hukum adat.

\section{Tiga Gerakan Moral sebagai Sarana Mewujudkan Kesejahteraan Masya- rakat}

UUD Negara Republik Indonesia Tahun 1945 merupakan dasar dari seluruh peraturan yang berlaku di Indonesia. Dengan kata lain, seluruh sendi peraturan baik dalam bentuk tertulis maupun tidak tertulis, tidak boleh bertentangan dengan konstitusi tersebut. Demikian pula pencanangan
Tiga Gerakan Moral di Kabupaten Sumba Tengah didasarkan pada konstitusi. Tiga Gerakan Moral merupakan pengakuan bahwa masyarakat memiliki hak hidup dan untuk mempertahankan hidup sebagaimana diatur dalam Pasal 28A UUD NRI 1945. Dengan adanya jaminan ini maka seluruh warga masyarakat berhak untuk mengusahakan berbagai cara guna mempertahankan hidup dan kehidupannya. Termasuk didalamnya untuk bekerja di kebun atau beternak. Dalam rangka itu dijamin pula hak warga negara untuk mengembangkan diri melalui pemenuhan kebutuhan dasarnya demi meningkatkkan kualitas hidup dan kesejahteraan sebagaimana diatur dalam Pasal 28C ayat (1) UUD NRI 1945).

Konstitusi juga memastikan bahwa warga negara juga memiliki hak untuk bekerja dan mendapatkan imbalan (Pasal 28D ayat 2 UUD 1945). Dengan demikian diketahui bahwa bekerja merupakan hak masyarakat, sehingga apabila Tiga Gerakan Moral khususnya gerakan kembali ke kebun mengajak masyarakat untuk bekerja merupakan bentuk dari pelaksanaan hak yang dijamin konstitusi. Bekerja pada dasarnya juga merupakan sarana untuk meningkatkan kesejahteraan, karena upah yang diterima dapat dipergunakan untuk mencukupi kebutuhan hidup. Hal ini terkait dengan hak yang dimiliki oleh setiap warga negara untuk hidup sejahtera lahir dan batin (Pasal 28H ayat 1 UUD NRI 1945). 
Tiga Gerakan Moral juga sesuai dengan Pasal 33 UUD 1945 yang menetapkan bahwa perekonomian nasional diselenggarakan berdasar atas demokrasi ekonomi dengan prinsip antara lain berkelanjutan dan berwawasan lingkungan. Tiga Gerakan Moral dimaksudkan agar perekonomian di Sumba Tengah dapat terlaksana secara berkelanjutan. Diperhatikan pula bahwa gerakan yang dicanangkan didasarkan pada keadaan lingkungan Sumba Tengah. Oleh karenanya jelas bahwa gerakan ini sesuai dengan Pasal 33 ayat 1 UUD 1945. Selanjutnya diketahui pula bahwa pada tiga gerakan di Sumba Tengah, ada peran pemerintah di dalamnya. Hal ini merupakan salah satu bentuk dari pelaksanaan tugas pemerintah untuk memelihara fakir miskin sesuai dengan amanat konstitusi dalam Pasal 34 ayat 1 UUD 1945.

Salah satu dari Tiga Gerakan Moral tersebut adalah Gerakan Desa Aman, sesungguhnya gerakan ini merupakan pengakuan bahwa setiap orang berhak atas perlindungan dan kepastian hukum (Pasal 28 G ayat 1 UUD 1945). Selain itu Gerakan Desa Aman juga sesuai dengan amanat konstitusi dalam Pasal 28 G ayat 1 yang mengatakan bahwa setiap orang berhak atas perlindungan diri pribadi, keluarga, kehormatan, martabat dan harta benda yang dibawah kekuasaannya.

Berlandaskan pada seluruh uraian tersebut di atas, maka jelas bahwa Tiga Gerakan Moral yang dicanangkan dan dilaksanakan di Sumba Tengah sesuai dengan konstitusi negara Indonesia. Hal ini menunjukkan bahwa meski Tiga Gerakan Moral tersebut berlaku sebagai hukum adat akan tetapi tidak bertentangan dengan hukum dasar negara Indonesia yaitu Pancasila dan UUD NRI 1945. Salah satu tujuan negara Indonesia sebagaimana tertuang dalam Pembukaan UUD NRI 1945 alinea ke 4 adalah memajukan kesejahteraan umum. Kondisi sejahtera terjadi manakala kehidupan manusia aman dan bahagia karena kebutuhan dasar akan gizi, kesehatan, pendidikan, tempat tinggal, dan pendapatan dapat dipenuhi. Kesejahteraan juga terjadi manakala manusia memperoleh perlindungan dari resiko-resiko utama yang mengancam kehidupannya. Kesejahteraan adalah sesuatu yang sudah seharusnya diusahakan oleh masyarakat bersama-sama dengan negara. Hal ini dimengerti sebab masyarakat adalah bagian terbesar dari sebuah negara, oleh karenanya tujuan negara mustahil dapat tercapai tanpa peran serta dari masyarakatnya.

Tiga Gerakan Moral di Sumba Tengah merupakan salah satu cara dari masyarakat bersama Pemerintah Daerah untuk mengusahakan terwujudnya kesejahteraan masyarakat, seperti dijelaskan demikian. Pertama, Gerakan Kembali ke Kebun, merupakan ajakan untuk mengolah kekayaan alam berupa lahan pertanian/perkebunan dan peternakan. Hal ini dilakukan mengingat potensi sumber daya lahan untuk pengembangan pertanian dan peter- 
nakan yang cukup besar. Manakala potensi sumber daya lahan tersebut dikelola dan diusahakan dengan baik, akan memberi nilai tambah bagi masyarakat yaitu keragaman dan ketahanan pangan. Pada gilirannya masyarakat dapat bebas dari kelaparan ketika usaha pertanian di lahan basah (sawah) tidak memberi hasil yang maksimal. Hasil dari pengolahan lahan kebun berupa tanaman alternatif akan digunakan tidak saja untuk konsumsi, tetapi juga untuk perdagangan sehingga memberi tambahan ekonomi. Hasil perdagangan dapat disimpan/ditabung untuk digunakan membiayai kebutuhan rumah tangga, pendidikan anak dan kesehatan.

Kedua, Gerakan Hidup Hemat, merupakan gerakan yang ingin mengajak masyarakat Sumba Tengah kembali pada nilai-nilai budaya asli agar tetap memiliki jati diri. Gerakan ini lahir dari pergeseran pola penggunaan hewan ternak dalam upacara adat yang kemudian beralih menjadi ajang pamer kekayaan dan gengsi. Dengan adanya pembatasan jumlah ternak yang boleh dilibatkan dalam acara-acara adat (baik perkawinan, kematian, dan pesta) merupakan bentuk penghematan. Pada gilirannya, penghematan ini tidak saja mempertahankan populasi ternak tetapi juga dapat digunakan untuk hal-hal yang lebih bermakna tinggi seperti kebutuhan hidup rumah tangga, dukungan pendidikan anak dan biaya kesehatan. Jika terjadi pergeseran pola perayaan adat-istiadat, maka biaya yang semula digunakan untuk perayaan adat dimaksud dapat digunakan untuk kebutuhan lain yang mendasar seperti pendidikan dan kesehatan.

Ketiga, Gerakan Desa Aman, merupakan gerakan yang dilatarbelakangi oleh kesadaran bahwa Gerakan Kembali ke Kebun dan Gerakan Hidup Hemat membutuhkan dukungan berupa situasi yang aman dan tenteram. Masyarakat yang merasa aman dan tenteram akan menjadikan dirinya nyaman dan leluasa dalam menjalankan aktivitas kesehariannya, baik aktivitas rumah tangga maupun dalam menjalin relasi dengan sesamanya. Kondisi keamanan dan ketertiban dapat mendorong warga masyarakat melakukan kegiatan pemeliharaan ternak (baik ternak besar dan kecil) maupun mengusahakan tanaman di lahan pertaniannya. Aktivitas ini tentu mendukung ketahanan pangan dan kondisi ekonomi rumah tangga, yang pada gilirannya membantu terwujudnya kesejahteraan masyarakat.

Berdasarkan uraian di atas, semakin jelas dan terang bahwa Tiga Gerakan Moral yang dicanangkan dan merupakan komitmen menyeluruh masyarakat Kabupaten Sumba Tengah merupakan salah satu upaya bersama dari Pemerintah Daerah dan Masyarakat untuk ikut mewujudkan salah satu tujuan bangsa Indonesia yaitu mewujudkan kesejahteraan umum.

\section{PENUTUP}

Beranjak dari uraian sebelumnya 
dapat disimpulkan beberapa hal berikut. Tiga Gerakan Moral Kabupaten Sumba Tengah merupakan respon untuk mengatasi tiga permasalahan mendasar yaitu pergeseran pola bertani masyarakat yang mengutamakan sawah, kecenderungan hedonisme yang bertamengkan adat istiadat, serta tidak terkendalinya masalah ketentraman ketertiban masyarakat. Tiga Gerakan Moral merupakan cerminan dari adat istiadat yang telah ada sebelumnya, sehingga gerakan tersebut bukanlah bermaksud mengubah adat istiadat, namun melakukan pemurnian dan penghargaan terhadap adat istiadat yang telah lama tumbuh dan berkembang secara turun temurun di kalangan masyarakat Sumba Tengah.

Terkait dengan hal tersebut di atas, Tiga Gerakan Moral - yang merupakan adat - melahirkan Hukum Adat. Dikatakan sebagai hukum adat karena memenuhi persyaratan atau kualifikasi seperti adanya norma/ hukum, ada sanksi dan penegak sanksi serta ketaatan dari masyarakat. Selain itu, Tiga Gerakan Moral tersebut memiliki basis atau landasan filosofis, sosiologis dan yuridis, sehingga mempunyai kekuatan mengikat bagi masyarakat. Eksistensi Tiga Gerakan Moral sebagai hukum adat tetap diakui dalam keterkaitan dengan hukum nasional. Hal ini karena secara konstitusional ada pengakuan dan penghargaan terhadap hukum adat, sepanjang memenuhi beberapa persyaratan yang telah diuraikan sebelumnya. Pada akhirnya, Tiga Gerakan Moral tersebut juga sejalan dengan tujuan negara untuk mencapai kesejahteraan bagi masyarakatnya.

\section{DAFTAR BACAAN}

\section{Buku dan Makalah:}

Dwi Santoso, Agus, Peran Dan Fungsi Kedudukan Hukum Adat Dalam Sistem Hukum Nasional Dalam Rangka Penguatan Dan Pelestarian Nilai-Nilai Adat Istiadat Di Daerah (1999).

Hadikusumah, Hilman, Pokok-Pokok Pengertian Hukum Adat, (Alumni 1980).

IGN Sugangga, Hukum Peranan hukum Adat dalam Pembangunan Indonesia (Pidato Pengukuhan Guru Besar Hukum Adat, UNDIP, 1999).

Irianto, Sulistyowati \& Shidarta (Editor), Metode Penelitian Hukum: Konstelasi dan Refleksi (Yayasan Pustaka Obot Indonesia, 2011).

Istanto, Sugeng F, Penelitian Hukum (CV Ganda, 2007).

Soekanto, Soerjono dan Sri Mamuji, Penelitian Hukum Normatif Sebuah Tinjauan Singkat (Rajawali Pers, 1990).

Soepomo, R., Bab-Bab tentang Hukum Adat (Pradnya Paramita, 2003).

Rauta, Umbu, et.al., Tiga Gerakan Moral (Perspektif Historis, Filosofis, Yuridis dan Sosiologis), Kerjasama Fakultas Hukum UKSW dengan Pemerintah Kabupaten Sumba Tengah, 2012. 
Tanya, Bernard L., et.al., Teori Hukum Strategi Tertib Manusia Lintas Ruang dan Generasi (Genta Publishing, 2010).

\section{Perundang-undangan \& Dokumen Lainnya}

Undang-Undang Dasar Negara Republik Indonesia Tahun 1945.

Undang-Undang Nomor 32 Tahun 2004 tentang Pemerintahan Daerah

Undang Undang Nomor 23 Tahun 2014 tentang Pemerintahan Daerah

Peraturan Pemerintah No. 15 Tahun 2010 tentang Percepatan Penanggulangan Kemiskinan.

Peraturan Pemerintah No. 18 Tahun 2010 tentang Usaha Budidaya Tanaman

Rencana Pembangunan Jangka Menengah Daerah (RPJMD) Sumba Tengah Tahun 2009 - 2013, Bappeda Kabupaten Sumba Tengah, 2009.

Kesepakatan Tiga Gerakan Moral Tiap Kecamatan se Sumba Tengah, Bagian Hukum Setda Kabupaten Sumba Tengah 2010.

Buku Panduan Tiga Gerakan Moral Kabupaten Sumba Tengah, Bagian Hukum Setda Kabupaten Sumba Tengah, 2010. 
[Vol. 1, No. 2 